\title{
$\underline{\text { An Adversarial Ethics of Campaigns and Elections }}$
}

\author{
Samuel Bagg and Isak Tranvik \\ NB: this is the "author-approved" version (AAV) of the manuscript \\ (i.e., the final draft after peer review and before publisher edits)
}

Journal: Perspectives on Politics 17(4)

Accepted: 5 April 2019

Published online by Cambridge: 20 September 2019 (link; doi: 10.1017/S1537592719002639) AAV available on academia.edu: 20 September 2019 (link)

\begin{abstract}
Existing approaches to campaign ethics fail to adequately account for the "arms races" incited by competitive incentives in the absence of effective sanctions for destructive behaviors. By recommending scrupulous devotion to unenforceable norms of honesty, these approaches require ethical candidates either to quit or lose. To better understand the complex dilemmas faced by candidates, therefore, we turn first to the tradition of "adversarial ethics," which aims to enable ethical participants to compete while preventing the most destructive excesses of competition. As we demonstrate, however, elections present even more difficult challenges than other adversarial contexts, because no centralized regulation is available to halt potential arms races. Turning next to recent scholarship on populism and partisanship, we articulate an alternative framework for campaign ethics, which allows candidates greater room to maneuver in their appeals to democratic populations while nevertheless requiring adherence to norms of social and political pluralism.
\end{abstract}

Key Words: elections; campaigns; adversarial ethics; democratic theory; competition; pluralism

Acknowledgments: For feedback and discussion, the authors are very grateful to Alex Kirshner, Wayne Norman, Michael Munger, and several anonymous reviewers. 


\section{Introduction}

"When they go low," Michelle Obama announced to roaring applause at the 2016 Democratic National Convention, "we go high." It was the most memorable line of her speech, if not the entire convention, and it soon became a slogan for supporters of Hillary Clinton's unsuccessful bid for the US presidency. "Going low" was a reference to a barrage of unsavory tactics employed by Clinton's Republican opponent, Donald Trump, while “going high" was posited as the appropriate response to Trump's “ugliness” (Hellmann 2016). Indeed, the idea of going high functioned as a kind of rallying cry among liberal elites seeking to defend democracy from what they perceived to be an existential threat. But is it the right thing to do?

That, roughly, is the question we ask in this article. We do not analyze the 2016 election in any detail, and we do not comment on whether concerns about the death of democracy were well founded in that instance. Instead, we treat the widespread recent discussion of these issues as an invitation to think through a fundamental theoretical question of political ethics, whose relevance is far broader than a single campaign: What kinds of normative considerations ought to guide or constrain the strategic choices facing candidates for political office in a democracy? What means can well-intentioned candidates use in their quest to win elections, without threatening the democratic norms on which the value of elections depends?

We are not alone in our conviction that this question deserves serious considerationespecially in our current political moment. Facing the disturbing spread of "authoritarian backsliding" around the world (Dresden and Howard 2016), many political scientists warn that growing polarization — often compounded by campaign tactics meant to mobilize voters — may endanger democratic norms (Mickey, Levitsky, and Way 2017). Yet the question of how candidates should conduct themselves in campaigns is rarely considered in political ethics and 
democratic theory. Among the few existing accounts of campaign ethics, meanwhile, none has properly accounted for the inherently adversarial nature of elections.

As scholars in the tradition of "adversarial ethics" observe, competitive practices like sports, trials, and markets present special ethical dilemmas, because they often incentivize or even require behaviors of participants that are normally considered unethical. Although few would ban such practices outright, we also do not want to cede these competitions to actors who are willing to sacrifice ethical principles to succeed. Adversarial ethicists outline two possible strategies for avoiding this perverse result: either excusing the unethical behavior, thereby enabling ethical participants to compete on equal terms, or disincentivizing it through reliably costly sanctions (Applbaum 2000; Heath 2006; Singer 2018).

Elections give rise to a similar dilemma: although they present strong incentives for otherwise unethical adversarial behavior, few see this as a reason to abandon electoral competition altogether. Previous accounts of campaign ethics, however-which are focused primarily on candidate honesty-rarely if ever excuse unethical behaviors on the campaign trail; in fact, they usually conclude that candidates have stronger ethical duties than ordinary citizens. Neither do they consider how deceptive behaviors might be effectively disincentivized. In real-world democracies, therefore, such idealized accounts of campaign ethics threaten to have perverse consequences. If some forms of dishonesty are electorally beneficial — as the widespread use of deceptive tactics suggests - then candidates who persist in upholding perfect honesty will likely be weeded out of the competition, ceding the electoral process to the least scrupulous. ${ }^{1}$

\footnotetext{
${ }^{1}$ We cannot definitely prove whether such strategies are, in fact, effective. However, most candidates appear to believe they are, and as we discuss later, there are good reasons for this belief. As such, we are interested in the theoretical questions that arise when such strategies are effective or when candidates reasonably believe they are.
} 
We propose a different framework for grappling with the important questions facing candidates for office. Existing accounts have emphasized honesty because they seek to preserve a pristine principal-agent relationship between citizens and elected officials. In our view, however, this idealized model of the citizen-officeholder relation is naïve, and no real-world democracy could even approximate it. ${ }^{2}$ If theories of campaign ethics are to be useful to candidates, as we believe they should, they must be oriented toward a more realistic account of the value and aims of democratic institutions. ${ }^{3}$ Although it is beyond the scope of this article to articulate such an account, we follow "democratic realists" in assuming that the actual virtues of democracy have more to do with the beneficial effects of party competition than with accurate reflection of a coherent popular will (Bagg 2018b; Przeworski 1999, 2010, 2018; Shapiro 1999, 2016). ${ }^{4}$ Accordingly, we propose an account of campaign ethics centered on preserving the benefits of this competition for all members of the community—or, in other words, on the values of social and political pluralism.

Unlike the ideal of preserving principal-agent representation through scrupulous candidate honesty—which is both impossible to achieve and unnecessary for democratic politics—defending pluralism is at once within our grasp and essential to the real value of democracy. Unlike existing honesty-focused accounts, moreover, our pluralist account of campaign ethics is directly addressed to the most important category of ethical dilemmas that candidates are actually likely to face. In

\footnotetext{
2 As we explain in more detail later, there are a number of reasons for skepticism about the principal-agent model, including empirical evidence about typical voter behavior and theoretical models of social choice procedures. For an overview, see Achen and Bartels 2016.

3 In this sense, our account is broadly aligned with a recent turn in political philosophy toward modes of theorizing that are "realistic" as opposed to "idealized" or "moralized"; see Galston 2010. This turn is associated with distinct but overlapping literatures on political realism and non-ideal theory, and our approach certainly has affinities with work in both traditions. However, the precise meaning of terms like "realism" are hotly contested (Baderin 2014; Sleat 2016), and we do not have space to position our approach in relation to any specific account, although see Bagg 2016, $2018 \mathrm{c}$. As a result, we are satisfied to note a shared orientation, in a broad sense, toward more realistic theorizing.

${ }^{4}$ In a more general sense, our approach is also aligned with a turn toward "realistic" approaches to democratic theory; see Green 2009; Maloy 2013; Medearis 2015.
} 
particular, when a candidate's substantive goals are ethically valuable-and the interesting dilemmas of campaign ethics arise only when they are or could be-serious normative trade-offs may arise between the obligation to attain these valuable ends and the obligation to sustain healthy democratic norms and procedures. Only our pluralist account addresses these trade-offs head-on.

Of course, the framework we propose can hardly claim to resolve all such dilemmas. Indeed, we offer only preliminary suggestions about the substantive recommendations that follow from such a framework: our primary task is to shift the focus of campaign ethics, more generally, from honesty to pluralism, and that requires most of our attention. Nevertheless, our account has three crucial advantages over its rivals. First, norms against anti-pluralism are more likely to be enforceable through decentralized sanctions, meaning that candidates can follow them without ceding the field to the least scrupulous competitors. Second, even when such decentralized enforcement fails — which it certainly does from time to time-abiding by these norms is still less likely to harm the electoral fortunes of well-meaning candidates than maintaining strict honesty. Third and finally, upholding pluralism is ultimately more crucial for safeguarding the benefits of democratic institutions. As a result, we conclude that our pluralist approach to campaign ethics provides more reliable action guidance to ethical candidates who seek to achieve valuable substantive ends while preserving and extending democracy.

\section{Campaign Ethics: The Limits of Existing Accounts}

Although there is an extensive body of literature dedicated to examining which campaign strategies and tactics are most effective, relatively little work has sought to establish what strategies and tactics count as ethical. Meanwhile, those who have addressed the topic have emphasized candidate honesty, in service of an implicit principal-agent model of representative politics. For instance, Stephen Medvic and Dale Miller endorse a "civic responsibility" approach to campaign 
ethics. Because they believe "campaigns are public debates about how society should operate," Medvic and Miller argue that candidates "must act according to standards that encourage rational decision-making by voters" $(2002,28)$. For campaign discourse to be ethical, then, it must "expose the arguments of both sides," "facilitate the identification of distortions and of false statements of fact," and clearly state candidates' "views and intentions" (28). ${ }^{5}$ While acknowledging the difficulties of adhering to such a standard, Medvic and Miller conclude it is preferable because "it better serves the public good" than the alternatives they consider (34).

Other accounts focus less on the generalized quality of public debate and more on the specific claims made by candidates for public office, but they also emphasize that the honest transmission of information is crucial for democratic government. L. Sandy Maisel, for instance, argues that candidates must be "open and honest" so that voters can make an informed choice about who best represents their interests $(2002,44)$. If voters do not know what their representatives will do once in office, he claims, elections cannot legitimize the authoritative decisions of public officials. Keena Lipsitz, meanwhile, draws on theories of deliberative democracy to argue that candidates must give "reasons for positions taken," "be consistent," "be civil," "engage the arguments of others," and "speak to the concerns of all constituents" $(2004,174)$. When candidates fail to follow these guidelines, she argues, voters cannot make informed and reasonable choices about who best represents them. Like Maisel, then, Lipsitz believes that the legitimacy of representative democracy depends on forthright communication between candidates and ordinary citizens.

In the most recent treatment of the subject, Eric Beerbohm argues that candidates in democratic elections regularly solicit trust from citizens by making truth claims, as well as "second-personal," “promissory" speech acts $(2016,395-96)$. Thinking of campaign discourse in this way, Beerbohm

\footnotetext{
${ }^{5}$ This list is not exhaustive. The authors note that these criteria were originally developed by Stanley Kelly Jr.
} 
argues, "has the potential to alter the agency relationship of citizens to their lawmakers, guarding against the inherent vulnerability of the ordinary citizen in a representative system" (405). As a result, candidates are morally obligated not to exhibit behaviors, such as lying, bullshitting, pandering, mudslinging, and strategic ambiguity, which might betray the trust that protects the citizen from the "power imbalances built into representative democracy" (382) . Beerbohm's "relational model" emphasizes the trust solicited by candidates' statements, rather than the information they convey. But it still requires nearly perfect honesty of candidates as a strict condition of democratic legitimacy because of its reliance on a principal-agent model of citizencandidate relationships in a democracy. Although Medvic and Miller, Maisel, and Lipsitz do not explicitly endorse a similar principal-agent model, each of their accounts seems to be underpinned by it: voters need accurate information to make electoral decisions that reflect their interests. Because campaigns are the primary mechanism by which that information is transmitted, they must be conducted in an open and honest manner.

Given the dearth of attention devoted to campaigns in democratic theory, especially considering their central importance in most citizens' experience of democracy, these contributions are laudable. Indeed, we endorse the common thread that weaves them together: candidates make claims that citizens rightly expect them to uphold. In our view, however, these accounts do not sufficiently account for two crucial features of elections, which any useful, nonself-undermining guidance to candidates must account for. The first is that campaigns are largely unregulated and highly competitive. The second is that the outcome of elections often has very significant moral weight. As we shall see, it is the combination of these two features that makes campaign ethics a uniquely difficult problem. In fact, the problem is unresolvable if one's account 
of campaign ethics is designed to protect the principal-agent relationship between citizens and representatives.

We are not the first to note that campaigns are competitive affairs nor that this aspect of liberal democratic government is critical to its value. Perhaps most famously, Joseph Schumpeter (1942) argued that democracy's normative appeal is largely a function of its hotly contested elections. And although Schumpeter's elite-driven model is generally unpopular among normative theorists, many maintain the more general principle that competition of some kind is both necessary and desirable (Connolly 1991; Kirshner 2016; Medearis 2015; Mouffe 2005; Shapiro 1999). We agree with such authors that competition is essential to democratic government, because it strengthens the state's resistance to capture at the hands of any particular elite or faction (Bagg 2018b). We also recognize, however, that competitive incentives can generate "arms races" that erode democratic norms and institutions. If we are to endorse and encourage competition as an integral part of democratic politics, therefore, we must devote more attention to forestalling such dynamics before they threaten democracy from within.

Existing efforts to theorize campaign ethics yield few resources for solving this problem. Because they say little about what ethical candidates should do when their opponent refuses to play by the theorists' rules, they fail to address what we believe to be the central ethical dilemma facing real candidates in real democracies: how to weigh the demands of justice and other substantive ends against the imperative of maintaining healthy democratic procedures. ${ }^{6}$ Fortunately, however, we need not start from scratch: ethicists of sports, law, and business have

\footnotetext{
${ }^{6} \mathrm{We}$ do not mean to imply that there is no value in considering the attitudes or character of individual candidates. Indeed, we are sympathetic to efforts stressing a more flexible virtue ethics (as opposed to deontological) approach to campaigns, such as that of Galston (1991). That said, we believe that we cannot rely on candidates alone to do what they are supposed to. The benefits of cheating are too high and the costs too low, while the stakes are often enormous. As such, we must attempt to establish norms that can be enforced with decentralized sanctions. Although Galston appears to gesture toward such standards (195), he does not articulate them in any detail and does not explicitly address the difficulty of decentralized enforcement.
} 
been grappling with similar dilemmas for some time in a burgeoning literature known as "adversarial ethics," and we can learn a great deal by applying this framework to the ethics of campaigns and elections.

\section{Adversarial Ethics: Realistic Principles for the Playing Field, the Courtroom, and the Market}

The observation that motivates the study of adversarial ethics is that in adversarial contexts such as sports, jury trials and competitive markets, we sometimes allow or even endorse certain behaviors that are otherwise considered unethical. As in democratic elections, competition can be beneficial in these domains, yet adversarial ethicists also recognize that in creating incentives to engage in otherwise unethical behavior, adversarial institutions carry their fair share of dangers. If highly compensated defense attorneys are so committed to exonerating their clients that they are willing to go beyond misleading cross-examinations and actually fabricate evidence, for instance, juries have no reliable way to distinguish between the guilty and the innocent. Similarly, the more businesspeople attempt to generate monopoly rents or exploit market failures, the fewer benefits competitive markets will have for society. The challenge of adversarial ethics is thus to excuse certain competitive behaviors while effectively disincentivizing those that are purely destructive.

How can destructive behaviors be reliably prevented? First, of course, the sincerely held ethical principles of competitors can always inhibit foul play without regard to external incentives. Cyclists, for instance, may refrain from doping simply because they consider it immoral, even if it is in their "interest" to take banned substances. Second, informal norms enforced by decentralized sanctions may also govern competitors' behavior. Codes of sportsmanship, for example, effectively induce soccer players to kick the ball out of bounds when an opponent gets injured and MMA fighters to stop immediately when their opponents tap out. Third, finally, there are formal 
rules in sports, trials, and markets — often designed to limit the harms of competition - that are enforced by an impartial referee, judge, or regulator.

In our view, a key contribution of the adversarial ethics approach is the recognition that different kinds of constraints are appropriate in different circumstances, and, in particular, that there are often serious limits on the effectiveness of the first two mechanisms: i.e., ethical principles and informal norms (Norman 2011; Singer 2018: 251-54). If an unethical behavior like doping confers a large enough advantage, for instance, it is only a matter of time before some athletes adopt it. Once that happens, even those who initially avoided the behavior must follow suit or drop out of the competition, ceding the field to the unscrupulous. If the benefits of the behavior are substantial enough, the situation is ripe for an arms race dynamic, in which all competitors must keep up with the unethical behavior of violators to stay in the game.

In sports, law, and business, this is precisely when recourse to the third strategyformalization of rules and centralization of enforcement - is often required. Preventing an arms race can be very difficult without formal rules and centralized authority to enforce them. As codes of sportsmanship demonstrate, informal norms may effectively constrain competitors, but there is a reason that such codes do not require athletes to seriously endanger their chances of winning. Once a socially destructive strategy becomes too advantageous, the incentives for victory will begin to outweigh the limited costs of violating informal codes. Rather than subjecting competitors to such temptation, therefore, we try to make these strategies formally illegal.

What, then, is the obligation of ethical athletes or businesspeople when they discover an opportunity to gain some advantage by unethical means? First of all, clearly, they should abstain from taking advantage of it themselves. From an ethical perspective, at least, it is obvious that they 
should not act immorally simply because it is in their interest to do so. Yet unless it goes beyond this minimal recommendation, adversarial ethics will be condemned to irrelevance.

If there are no centrally enforced rules, after all, it does not matter how many principled cyclists refuse to engage in doping. Eventually, someone will start taking banned substances. Given the arms race dynamic discussed earlier, doping will sooner or later become necessary for victory. As a result, an ethical approach recommending only that competitors abstain from such profitable but destructive practices is a pointless (if not counterproductive) enterprise. In our view, an adversarial ethics that aspires to be impactful must offer more than this abstinence-only approach. It must also require actors to identify potential arms race dynamics and try to halt them before they get out of hand.

An ethical businessperson who encounters an opportunity to profit through some socially destructive practice, for instance, should not stand by and wait for her company to be driven into bankruptcy by the first unscrupulous competitor to discover and exploit it. In addition to abstaining from the practice herself, she must also try to change the circumstances that render it profitable; that is, she should try to raise the costs of engaging in that destructive practice. This may mean advocating informal norms, like codes of sportsmanship, or making semiformal agreements to "self-regulate" among the relevant competitors. If the incentives for violating these norms are too high, however, or if decentralized enforcement is unlikely to be effective, then the relevant actors may be incapable of preventing an arms race by themselves. In such cases, it becomes the ethical businessperson's duty to lobby for formal, centralized enforcement. ${ }^{7}$

\footnotetext{
${ }^{7}$ Abraham Singer puts it this way: "We should think of businesses as having a moral obligation to pursue the types of regulation or professional agreements that would allow them to do the ethical thing that is otherwise strategically precluded" $(2018,252)$.
} 


\section{Campaigns and Elections as Adversarial Institutions}

\section{An Adversarial Approach to Campaign Ethics: Promises and Challenges}

Some of the dilemmas facing candidates in competitive elections, we submit, are structurally similar to those faced by ethical businesspeople. As campaign ethicists have pointed out, deceptive and dishonest tactics such as lying, pandering, misdirection, waffling, and incivility can have serious negative consequences. Yet such behaviors may also be "profitable" in electoral terms: indeed, certain campaign environments will be ripe for arms races in which all candidates use increasingly "dirty" tactics to keep up with their rivals, while those who eschew these tactics are more likely to be left behind. ${ }^{8}$ That is what previous approaches to campaign ethics have neglected to account for: not simply that destructive behaviors are sometimes rational but also that there may be circumstances where refusing to partake prevents ethical actors from remaining in the competition at all. Under such circumstances, only those who make unethical choices will even be presented with such choices again — and in this way, making ethical choices becomes actively selfundermining. ${ }^{9}$

We argue that adopting an adversarial approach can help us understand the responsibilities of candidates in such situations. More specifically, the responsibility of candidates to avoid profitable but destructive behaviors should be theorized on a continuum along with feasible ways of altering the circumstances that make those behaviors "profitable" in the first place. An ethical candidate should not deceive her potential constituents without reason, of course, but she should also not

\footnotetext{
${ }^{8}$ Clearly, many local and regional elections are not subject to arms race dynamics (perhaps because the stakes are lower). We consider the most cutthroat campaigns - usually national elections - to establish the limit case. Furthermore, we acknowledge that strategies like pandering and mudslinging in competitive campaigns are not directly analogous to taking performance-enhancing drugs before competing in a cycling race: the latter confers a demonstrable advantage in a way that the former does not. However, many candidates plausibly believe that certain dishonest campaign tactics confer substantial advantages, and the task of campaign ethics is to consider how they should respond, given that reasonable belief.

${ }^{9}$ For a more general treatment of the prospects of normative theory in an evolving ecosystem defined by participants' strategic choices, see Bagg 2017, 272-74.
} 
allow her opponents to use such tactics to their advantage. Instead, her first response should be directed at undermining their effectiveness. Perhaps she will only need to highlight their unethical nature, enforcing norms against them via informal means; or perhaps she will need to strike an agreement with her opponents, with the aim of preventing an arms race. ${ }^{10}$ Just like the ethical businessperson, the ethical candidate should not only abstain from destructive tactics but should also seek to reduce the electoral "profitability" of those tactics.

At this point along the continuum, however, two differences emerge between elections and other adversarial institutions. First, in the context of sports, law, and business, there is an (ideally) unbiased third party to adjudicate disputes about infractions - a role with no direct analog in democratic politics. As such, where the ethical businessperson can lobby for centralized enforcement as a last resort-and can negotiate for self-regulation in the shadow of this possibility - the ethical candidate cannot. Centralized enforcement of campaign norms is not strictly impossible, but giving regulators the power to silence or disqualify candidates on the basis of campaign discourse could seriously endanger the open, pluralistic society that elections are supposed to protect. It is a cure for the excesses of competition that is worse than the disease. As a result, the last resort of athletes, lawyers, and businesspeople is unavailable to candidates in democratic elections: arms races must be averted without the help of referees, judges, and regulators.

The second difference between campaigns and other adversarial institutions is that a candidate's “incentives" for winning may be moral, as well as material. If the attempts of an athlete or businessperson to implement informal norms or formal regulations against a destructive practice

\footnotetext{
${ }^{10}$ According to Galston (1991), this is exactly what nine candidates running for mayor of New York City did during the 1989 campaign, when they created a nonpartisan Committee on Decent Unbiased Campaign Tactics "to avoid appeals based on race, ethnicity, and other emotional divisions among the electorate" (192). Galston suggests that the committee was at least somewhat effective.
} 
are unsuccessful, after all, we would still think it wrong to participate in that practice. As long as her reasons for doing so are primarily material (or self-interested), rather than moral (or otherregarding) — which is usually true of athletes and businesspeople — her moral imperative to quit or close up shop is fairly clear. In electoral campaigns, however, a candidate's reasons for employing a particular tactic may themselves be moral. If the election has significant normative consequences, the question of whether or not to engage in the destructive behavior is a question internal to ethical theory. As a result, we cannot responsibly tell candidates to "quit" the competition, which we would usually advise athletes and businesspeople to do in similar circumstances.

Given these two differences, the key question that emerges regarding "dirty" campaign tactics is whether they are likely to be effectively constrained through informal, decentralized sanctions. Because formal rules are unavailable as a means of regulation, yet we cannot tell ethical competitors to quit, we must rely on such sanctions to prevent arms races. If they are at least plausibly effective, then the ethical responsibility of candidates is to ensure they are enforced; that is, make the dirty tactics unprofitable. If an arms race will ensue regardless, however, then candidates with important substantive goals may be excused for using some dirty tactics. If such tactics are effective, indeed ethical candidates may have a responsibility to use them.

\section{The Challenges of Informal, Decentralized Enforcement}

In practice, there are two kinds of obstacles to effective informal sanctions against many destructive campaign behaviors. Some are inherent to the ambiguity of the norm in question, and others result from the costs of sanctions. Sometimes norms are difficult to enforce because it is genuinely hard to tell what counts as an infraction, in other words, and sometimes the challenge is

that those meant to enforce the norm have significant incentives not to do so. In many cases, of 
course, it is the combination of these two challenges that renders norms particularly difficult to enforce via informal, decentralized means. ${ }^{11}$

Consider the difference between handshake conventions and norms prohibiting romantic advances in the workplace. The latter are ambiguous, first of all, in a way that the former are not. Barring exceptional circumstances, no one will disagree about whether Al has offered Betty his left or right hand, but there may be great disagreement about whether a particular action of Al's counts as sexual harassment or harmless flirtation-even among people who agree about the wrongness of sexual harassment in general. This ambiguity does not preclude the possibility of decentralized enforcement altogether, but it clearly makes coordination more difficult. Second, the sanctions that accompany handshake conventions are not typically very costly. When they areas is often the case with sexual harassment - even people who desire to enforce a norm in general may be reluctant to do so in particular cases. A senator, for instance, might sincerely believe that sexual harassment is wrong and may even enact sanctions against it in other circumstances, yet still look the other way when her partisan ally is accused of wrongdoing. ${ }^{12}$

Such straightforward hypocrisy is surely an important obstacle to decentralized enforcement of campaign norms as well. Imagine, for example, that a candidate clearly violates a norm. The only certain way to sanction him for doing so is to withdraw support or take action that will cause others to withdraw their support. Those who already support other candidates cannot withdraw their support from the violator, of course, and they already have ample incentive to induce others to do so. Among those who share the violator's substantive goals, meanwhile, implementing

\footnotetext{
${ }^{11}$ Other difficulties may arise if not everyone endorses the norm in question. Here, however, we assume full endorsement in order to isolate obstacles to enforcement that are inherent to the norm itself.

${ }^{12}$ The relevant "costs" here may be moral or material: to speak of costs simply means that applying sanctions yields outcomes contrary to the actor's preferences, which may be self-interested or other-regarding.
} 
sanctions will come at significant substantive cost. In many cases, this kind of sacrifice will not seem worthwhile.

Drawing on the example of Venezuela's descent into authoritarianism, Milan Svolik (2018) shows that this is a key reason why polarization threatens the maintenance of political norms. Svolik's survey experiment with Venezuelan voters supports the predictions of his formal model (and of common sense): if there are more people in the ideological "center," then there are more people — elites and ordinary citizens alike — who will be willing to sanction violators by switching their support. In a polarized society, however, the threat of this kind of punishment is less credible, because switching one's support will typically require a greater sacrifice in substantive terms.

Of course, this account considers only the most straightforward mechanism through which polarization might make norm enforcement more difficult. Svolik assumes that everyone agrees a violation has occurred and that everyone considers the violation to be destructive. Polarization comes in only after these facts have been established, giving partisans incentives to consciously ignore the violation. In real political life, however, polarization is also likely to cause problems for norm enforcement well before this juncture, by intensifying entirely genuine disagreements about what counts as a norm violation in the first place (Ahlquist et al. 2018).

According to a wealth of research about the phenomenon known as "motivated reasoning" (Kunda 1990) or "identity-protective cognition" (Kahan et al. 2007), for instance, human beings systematically underconsume and undervalue information that contradicts our prior commitments and group identities (Bartels 2002; Lodge and Taber 2013). We do not seek out such information and, even if we are exposed to it, we are likely to ignore it, discredit it, or underestimate its importance — and then forget about it later. On the one hand, then, the information partisans receive will be quite different; and on the other hand, the way they interpret that information will also vary 
widely. Our prior commitments and group identities thus profoundly shape the way that we genuinely perceive the world - and in a polarized society, partisans of opposing camps are often likely to disagree in entirely sincere terms about whether norms have been violated (Bagg 2018a).

This outcome is all the more likely, of course, as the ambiguity of the norms in question increases, thereby making motivated reasoning more difficult to detect and counteract. Ambiguity also gives plausible deniability to those who are consciously underenforcing, like the senator who ignores her colleague's misdeeds. Given the difficulty of norm enforcement even when the violation is clear, this problem is only exacerbated the more room there is for disagreement about what counts as a violation. As a result, norms governing campaign discourse will be extremely fragile. Commitment to them must outweigh powerful substantive concerns and identity loyalties, which distort our ability to enforce norms in both conscious and unconscious ways.

We do not mean to suggest that it is impossible to sustain any norms of political discourse in the context of campaigns. Norms against incitement to vigilantism and political violence, for instance, are effectively enforced in most stable democracies. Black activists outraged by racialized police violence and mass incarceration almost universally disavow the logic and rhetoric of extrajudicial revenge, as do the vast majority of antiabortion activists convinced that federal law authorizes a genocide of the unborn. Calls for illegal violence are rare, and when they do occur, those who make them are marginalized even by their allies. The same can usually be said for norms against threats to undermine the integrity of elections or the rule of law, as well as certain forms of discourse that explicitly target racial and ethnic minorities. In other words, some campaign norms are enforceable, even in difficult circumstances. Nevertheless, we should not underestimate the difficulty of enforcing them. Sustainable enforcement requires that people who disagree on nearly everything else must not only agree about what counts as a violation but also coordinate on 
effective sanctions. When enforcement works-which it does, for certain violations, in all functioning democracies-we should celebrate it as the fragile achievement it is.

\section{Against an Abstinence-Only Ethics of Campaigns and Elections}

We can now state more clearly and comprehensively our reasons for transcending the focus on honesty favored by extant accounts of campaign ethics. In brief, many of the deceptive practices they prohibit are so ambiguous that cross-partisan enforcement will likely prove impossible. ${ }^{13}$ It will be too difficult for people across the political spectrum to agree on what counts as a violation, much less coordinate on costly sanctions. Wherever the incentives favoring certain deceptive practices are substantial, therefore, we can expect some noncompliance with norms against them, potentially yielding an arms race (or "race to the bottom"). Given a commitment to freedom of expression — and a healthy skepticism, in particular, of empowering regulators to silence political leaders - ethical candidates cannot turn to centralized enforcement of norms. Yet given the high normative stakes of many elections, they also cannot morally justify abandoning the competition altogether. If decentralized sanctions fail to undermine the profitability of certain forms of dishonesty, therefore, we conclude that ethical candidates ought to be excused for committing some forms of campaign deception.

To illustrate these claims more systematically, let us begin with the five deceptive practices prohibited by Eric Beerbohm-lying, bullshitting, pandering, mudslinging, and strategic ambiguity - which can fairly stand in for the range of honesty-focused guidelines offered to candidates by other campaign ethicists as well. We do not deny the prima facie ethical wrongs Beerbohm identifies with each of these practices. However, we submit that only a prohibition on

\footnotetext{
${ }^{13} \mathrm{We}$ are not claiming that these theorists have chosen the wrong norms to be enforced by decentralized regulation. Rather, we observe that they have not considered decentralized enforcement when establishing norms at all —and that this is problematic if one candidate in a competitive election does not follow the norms the theorist prescribes.
} 
lying is plausibly enforceable through decentralized sanctions. ${ }^{14}$ If blatant and consequential enough, lies can be identified and condemned across ideological lines, just like calls to violence and certain racially discriminatory remarks. When these norms are well enforced, an ethical candidate faces no dilemma at all: she has ample reason not to lie. Even in cases where these norms have been weakened, however, and lying might help her achieve her other normative goals, the ethical candidate should still refrain from doing so. Since norms against lying are sometimes enforceable, her first responsibility is to revive them — and lying clearly undermines that goal.

In the case of the other four behaviors Beerbohm classifies as morally off-limits, however, coordination on sanctions will be much more challenging, and this changes candidates' ethical calculus. Consider that it is difficult enough for two people with very similar substantive views to agree about whether a candidate has engaged in these practices. Generating enough agreement about such questions to induce coordinated sanctions across the political spectrum is very likely impossible. And although it is difficult to imagine circumstances where bullshitting would be essential to victory, it seems that candidates with valuable aims will sometimes be able to improve their chances of victory quite significantly by employing the other three strategies: strategic ambiguity, mudslinging, and pandering. As a result, the choice about whether to employ them looks quite different, from an ethical perspective, from the choice about whether to lie. Outright lying to voters is rarely if ever excusable, but ambiguity, mudslinging, and pandering might be.

We may consider the cases of ambiguity and pandering together. As a wealth of evidence demonstrates, ordinary voters are astonishingly poorly informed about both substantive issues and the track record of individual candidates (Achen and Bartels 2016; Somin 2013). Their policy

\footnotetext{
${ }^{14}$ Beerbohm would not necessarily deny this. For him, as for other campaign ethicists, enforcement is beside the point. Yet given the goal of providing useful action guidance to candidates - especially those whose opponents use a winat-all-costs approach-campaign ethicists ought to care more about enforcement. Otherwise, as we demonstrate in this section, they risk making recommendations that are ethically irresponsible.
} 
"preferences" exhibit little coherence across issues and only weak consistency over time, changing dramatically depending on the framing of the question. The problem of incoherence, meanwhile, only gets worse when considering dilemmas of social choice and the aggregation of preferences (Ingham 2018; Riker 1982). As individuals and as a society, it seems, we want contradictory things — better services and lower taxes, more security and stronger civil liberties — and who can blame us? Yet politicians will ultimately be called on to make choices between these priorities.

On the one hand, candidates can be fully honest about the trade-offs and uncertainties they face in making policy, presenting the same platform in the same precise way for every audience. On the other hand, they can remain strategically ambiguous about the finer points of policy while expressing hopeful optimism about their ability to solve problems, emphasizing different aspects of these hopes and dreams for different audiences. Given the typical behavior of voters, candidates who adopt the first strategy risk losing many supporters to candidates who adopt the second (promising better services and lower taxes, for instance). Where candidates must appeal to multiple audiences in multiple stages of an election, moreover - as in the American primary system - the problem is even more pronounced: the claims that resonate with one audience will differ substantially, by design, from those that appeal to the next. Without appealing to ambiguity or pandering, a perfectly honest candidate in such a system would seem to be at a huge disadvantage.

Consider the common connotations of the words "politician" and "political" as meaning "slippery" or "ambiguous," such that one who refuses to take a side is acting like a "politician" and dodging a question makes one's answer "political." This speaks not only to the frustrating quality of such tactics, of course, but also to their enduring effectiveness in democratic politics. Given what we know about voter behavior, it is unlikely that many voters will know or care about subtle differences between politicians' utterances across various contexts, and this enables 
politicians to get away with significant ambiguity. ${ }^{15}$ Given the divergent incentives they face in front of a wide range of different audiences, meanwhile, it is no surprise that many successful politicians maintain significant ambiguity or flexibility regarding their commitments.

Similar concerns can be articulated regarding prohibitions on mudslinging. As with the most blatant forms of pandering, there is some debate about whether and when negative campaigning is effective (Lau, Sigelman, and Rovner 2007). Where it seems clear that it will not be effective, however, there is no ethical dilemma to speak of. Meanwhile, its sheer prevalence again belies the supposition that it always fails to achieve candidates' goals. Whenever it appears to be effective, then, the candidate faced with a mudslinging opponent must choose between remaining on the defensive — and thereby accepting the "frame" proposed by her opponent (Lakoff 2004)—or going on the offensive herself, positing an alternative frame for voters to grab hold of. Again here, the correct choice in strategic terms is clear: by refusing to respond in kind to effective mudslinging by her opponents, she risks being uniquely tarred with damaging stigmas. As with ambiguity, refusing to engage in any mudslinging whatsoever could plausibly endanger a candidate's chances of winning — and when it does, retaliation may be the most responsible course of action.

If it were possible to enforce norms against strategic ambiguity, pandering, and mudslingingas it is with lying and calls to violence - this consequence might be averted. Unfortunately, this is not the case. Whether any given act counts as one of these deceptive practices, or as an acceptable form of rhetoric and opposition research, is often very ambiguous. Even among substantive allies, it will be very difficult to agree on whether violations have occurred. Coordination across party

\footnotetext{
15 Blatant pandering, of course, can sometimes be damaging to a politician's reputation and electoral chances (McGraw, Lodge, and Jones 2002). If so, however, there is really no ethical dilemma. Meanwhile, we are skeptical that pandering is never beneficial. For one, there is a sliding scale here from the most obvious forms of panderingwhich may be detrimental - to the subtler ambiguities and differences of emphasis that are the bread and butter of every democratic politician. Given their identity-driven behavior, moreover, it seems to us that ordinary voters are highly unlikely to be both able and willing to hold politicians accountable for minor pandering infractions.
} 
lines of mutual enmity and distrust will likely be impossible. We are left with a classic arms race, where those who eschew such strategies are placed at a significant disadvantage.

In other adversarial contexts, there is always one fail-safe option for maintaining one's ethical scruples: abandoning the competition altogether. What is at stake in at least some democratic elections, however, is not a gold medal or a bump in share price but matters of great normative importance. For this reason, we cannot simply say that candidates with valuable substantive goals should categorically refrain from ambiguity, pandering, or mudslinging, nor should they refrain from competing altogether. Both responses would significantly increase the likelihood that political power would be exercised by the least scrupulous actors. When there are morally important consequences for victory, therefore, any blanket prohibition on all forms of dishonesty will sometimes make for irresponsible recommendations. Instead, we claim that at least some forms of campaign dishonesty, under at least some circumstances, must be considered morally permissible (if not, in some cases, required).

Which forms of dishonesty are these, and under what circumstances will they be rendered permissible? Most obviously, unsanctionable deception or mudslinging from opponents and their allies will typically make it permissible for candidates to respond in kind. However, there may be other excusing or justifying circumstances as well. In fact, we expect that most candidates most of the time will not be fully forthright—-that is simply the way campaigns work—and it strikes us that even in the absence of specific, demonstrable instances of dishonesty by opponents, the demands of thriving within such an environment could plausibly serve as a general excuse for mild deceptive practices like pandering and ambiguity. Either way, the prevalence of such relatively trivial deception by candidates does not particularly concern us. On our "realist" account of democratic elections, after all, such commonplace deceptions represent minor distortions of a principal-agent 
relationship between citizens and officeholders that was largely fictional to begin with. As a result, they do not represent particularly serious wrongs, and they may be relatively easily excused. We think campaign ethicists—and candidates themselves—should focus their normative attention elsewhere. Rather than further analyzing the permissibility of various deceptions in relation to various hypothetical excusing circumstances, therefore, we turn now to articulate our alternative approach to the ethics of campaigns and elections, which emphasizes pluralism rather than honesty.

\section{Toward a Pluralist Approach to the Ethics of Campaigns and Elections}

Just as the benefits deriving from other adversarial institutions excuse some but not all competitive behaviors within those contexts, an adversarial ethics of campaigns cannot simply excuse all behaviors undertaken in pursuit of ends supposed to have independent normative value. Indeed, that is exactly why we believe the topic is so important: candidates do need guidance in deciding how to run their campaigns. In formulating this guidance, however, we must account for what we have learned from the shortcomings of extant approaches.

First, elections are fundamentally adversarial institutions, and this fact should be as central to the theory of campaign ethics as it is to ethical theories of sports, law, and business. Second, accounting for the adversarial nature of elections is especially difficult, because one of the tools available to adversarial ethicists in other domains — centralized enforcement—is unavailable in the context of campaigns. Where norms against certain dirty tactics are not likely to be enforceable through decentralized, cross-partisan sanctions, therefore, ethically proscribing those tactics will simply cede the political realm to the least scrupulous actors. Third, the focus on honesty favored by prevailing approaches to campaign ethics lends itself readily to such perverse consequences. 
As a result, campaign ethicists should refocus their attention; both framing their questions differently and emphasizing different democratic values in response.

\section{From Honesty to Pluralism: Standing Our Ground Where It Matters}

Let us be clear that we do not suggest abandoning honesty altogether. Deceptive practices such as ambiguity, mudslinging, and pandering do degrade the relationship between candidates and citizens to some degree, and candidates should avoid them whenever possible. Nevertheless, these mild forms of dishonesty are not nearly as threatening to democracies as other campaign ethicists have assumed, and in the darker moments of competitive campaigns, we think there are far more important places for candidates to stand their moral ground. In particular, we think that the most pressing moral dilemma facing ethical candidates - the one that might actually keep them up at night — is how to weigh the demands of maintaining democratic institutions against the prospect of achieving normatively valuable substantive policies. As a result, we think that a theory of campaign ethics should address this dilemma head-on. In doing so, moreover, it should focus on preserving those things that are truly necessary to democracy. ${ }^{16}$

On theories assuming that the purpose of elections is to enable ordinary citizens to "authorize" the laws through representatives conceived as agents of the people, of course, dishonesty by candidates does strike at the foundations of democracy's value (Beerbohm 2012). However, the principal-agent model of representation implied by this ideal—whereby representatives respond

\footnotetext{
${ }^{16}$ As an anonymous reviewer helpfully pointed out, this means that our framing of the questions of campaign ethics largely switches at this point from that of discovering the limits of permissible behavior-which is preferred by previous campaign ethicists - to that of weighing conflicting political values (very roughly, "procedure" vs. "substance"). As we interpret them, however, the two frames ultimately reduce to the same considerations in this case. Candidates behave most responsibly — and, therefore, permissibly — when they properly prioritize between these two pressing normative demands. Meanwhile, they behave irresponsibly - and potentially impermissibly — when they do so improperly. Thus, a candidate who prioritizes substantive goals over the most important pluralist normsdemonizing her opponents, for instance, to gain support for her policies - is behaving impermissibly: the damage to democracy is too grave. However, a candidate who prioritizes maintaining strict procedural norms of honesty over important substantive goals-thereby ceding the political field to the least scrupulous actors-also behaves irresponsibly (if not impermissibly): she fails to fight hard enough for justice.
} 
to exogenous citizen preferences - has long been understood by political scientists as highly unrealistic, if not incoherent (Disch 2011; Mansbridge 2003). Countless surveys and experiments demonstrate that most citizens have no opinion at all on most policy issues and that the opinions they have are not well informed (Achen and Bartels 2016; Lodge and Taber 2013). Meanwhile, social choice theory has exposed profound difficulties with the very idea of a popular will, which would persist even if everyone did have well-formed opinions (Arrow 1951; Riker 1982; Weale 2018).

In light of these findings, we should cease trying to preserve an idealized agency relationship between citizens and their representatives that was deeply implausible to begin with. It is simply not the case that elections would enable the people to authorize the laws, were it not for the strategic ambiguity of candidates. Yet elections seem valuable nonetheless, and in our view, the reason for this has more to do with competition between parties than with the fantasy that representatives could ever be said to make laws "in our name." ${ }^{17}$ We should still demand honesty from candidates, then, but it need not be our first priority. Other excesses of adversarial campaign competition are far more dangerous to democratic institutions.

It is beyond the scope of this article to develop a comprehensive theory of campaign ethics, much less a complete picture of healthy democratic institutions. Building on recent scholarship across several distinct traditions, however, we observe that many of the most dangerous tendencies of electoral competition seem to share an "anti-pluralist" character. Acceptable forms of partisanship and competitive behavior cross a line and become dangerous to democracy, authors such as Nancy Rosenblum and Jan-Werner Müller argue, when they lose their fallibilistic

\footnotetext{
${ }^{17}$ As we note earlier, we think competition is essential to democratic governance (Przeworski 1999; Schumpeter 1942). This is not necessarily because political competition produces the best public policies, but because it makes it more difficult for any single party or group to capture state institutions (Bagg 2018b). For the idea that laws are or ought to be made "in our name" - which implies the principal-agent model we reject—see Beerbohm 2012.
} 
character; that is, when they refuse to accept the legitimacy of disagreement. We suggest, therefore, that a focus on protecting social and political pluralism represents a more fruitful direction for campaign ethics: pointing out lines that might be tempting to cross in the name of valuable substantive goals, but that ethical candidates should nevertheless refrain from crossing.

In her study of the ethics of partisanship, for instance, Rosenblum acknowledges that all partisans think they are right. Those she calls "extremists," however, display "a deliberate and celebrated... single-mindedness," which ignores the fact of pluralism and excludes certain groups from consideration altogether (Rosenblum 2010, 401). In his analysis of populism, similarly, JanWerner Müller admits that all democratic politicians make claims on behalf of "the people." Yet those he calls "populists" (in a necessarily pejorative sense) make an "exclusive" and "moralistic" claim to representation - that "they, and only they, represent the people" while opponents are necessarily "part of the immoral, corrupt elite" (Müller 2016, 20). Although often claiming to represent the people, by contrast, nonpopulists concede "that representation is temporary and fallible, that contrary opinions are legitimate, that society cannot be represented without remainder, and that it is impossible for one party or politician permanently to represent an authentic people apart from democratic procedures and forms" (40). Other recent accounts have stressed a similar exclusionary, moralistic logic as central to populism, linking it both theoretically and empirically to the erosion of democratic norms and institutions (Galston 2018; Levitsky and Ziblatt 2018; McKean 2016).

Given that the normative valence of populism is seriously contested, we prefer to describe our target as "extremism" or "anti-pluralism," as in Rosenblum's account, rather than "populism," as Müller and others would have it. ${ }^{18}$ Regardless of the terminology employed, all of these authors

\footnotetext{
${ }_{18}$ Many scholars prefer to distinguish between democratic and antidemocratic forms of populism, rather than
} designating all populists as antidemocratic; see Boyte 2010; Bretherton 2014; Grattan 2016; Mouffe 2018. 
agree that the phenomenon in question is both endemic to electoral competition-in Müller's words, it is a "permanent shadow of representative politics" (2016, 101) — and seriously threatening to democracy. The logic of exclusive or direct representation suggests an all-toorecognizable set of polarizing strategies, which have proven frustratingly effective throughout the history of representative democracy and have been deployed by opportunists from a range of ideological backgrounds. The notion that one's opponents and their supporters are illegitimate and morally corrupt - perhaps not even part of the "real" people — has too often served as a potent justification for dismantling independent checks on centralized power (Levitsky and Ziblatt 2018, 72-96; Müller 2016, 44-49).

We propose that a more fruitful approach to campaign ethics would be oriented toward averting these dangers. Given its effectiveness in certain contexts, even candidates with valuable substantive goals may be tempted by hyperpolarizing, anti-pluralist rhetoric. Despite these temptations, a pluralist approach asks candidates to conscientiously address their arguments to the entire political community, thereby making themselves at least minimally accountable to all groups within that community. Some degree of polarization can be advantageous or even necessary in the fight for substantively valuable ends, but it can also make norm enforcement more difficult and, in some cases, slide into outright anti-pluralism. As a result, we maintain that ethical candidates should seek to minimize this polarization as much as they can and make conscious efforts to “depolarize" where possible. ${ }^{19}$ Meanwhile, genuinely anti-pluralist strategies must remain offlimits, even when the substantive stakes are very high.

For instance, candidates must vigorously attack their rivals—not only criticizing their policy positions but also highlighting their character flaws, unearthing past indiscretions, and exposing

\footnotetext{
${ }^{19}$ For a discussion of how community organizers use strategic polarization to achieve their goals-always followed by active efforts at depolarization-see Stout 2012.
} 
corrupt backroom bargaining. In doing so, however, they should accept the legitimacy of opposing politicians and refrain from demonizing them, casting them as morally corrupt outsiders in contrast to a morally pure in-group. Moreover, this license to attack one's political rivals does not extend to the ordinary people whose only vice is supporting those politicians. In particular, ethical candidates should not refer to their opponent or her supporters as "enemies" or label either as existential threats to the well-being of the political community-even when one suspects they might be. ${ }^{20}$ Such claims are particularly problematic (and deserving of sanction) when the targeted person or group can be identified by ascriptive characteristics, such as race, ethnicity, gender, and sexual orientation. Furthermore, we argue that it is not enough to refrain from attacking an opponent's supporters: even just ignoring a group can imply that its members do not deserve consideration as part of the polity. Instead, ethical candidates should work to include partisan opponents in their audience — answering their concerns and asking for their support—even if they recognize that such appeals are unlikely to be effective. ${ }^{21}$ Finally, ethical candidates should not pursue electoral strategies based on demobilizing opposition voters or discouraging participation in the democratic process more generally.

These demands are fairly extensive, of course, and we might wonder whether they overstep the bounds of campaign ethics, which ought to govern how people pursue their goals rather than which goals they pursue. Following our guidelines would seem to prevent ethnonationalist candidates, for instance, from presenting their ideas at all: even if they were perfectly willing to abide by the results of elections and adhere to other norms of democratic life, our account would

\footnotetext{
${ }^{20}$ Inevitably, there will be exceptions here in very extreme cases. For discussion, see Kirshner 2014.

${ }^{21}$ This does not mean pandering to ethnonationalists, for instance, by condoning racist beliefs or capitulating to their demands. Rather, it means offering a different interpretation of their concerns-highlighting whatever might be legitimate within them - and defending one's political platform as the best response to those charitably interpreted concerns. This may simply be impossible with certain populations: as noted earlier, these guidelines may need to be suspended in certain extreme cases. But we think such cases are quite rare, even in societies, like the United States that are deeply structured by racism.
} 
rule large swaths of their substantive platform out of bounds as a violation of campaign ethics. Even if we find their views repugnant in a broader sense, therefore, the objections we make may appear not to fit within the scope of campaign ethics. ${ }^{22}$

This objection, however, depends on a strict separation between values of social pluralismconcerning an inclusive society-and political pluralism-concerning open democratic procedures - which cannot be sustained. On the one hand, we think that the former is just as central to the value of democracy as the latter: the benefits of competition between parties are seriously undermined if some members of society are excluded from the audience, such that their interests may be entirely ignored. ${ }^{23}$ On the other hand, the work of scholars such as Rosenblum, Müller, and Levitsky and Ziblatt has revealed a clear connection in practice between the two forms of antipluralism, which we would be unwise to ignore. Candidates who reject "social" pluralism often reject "political" pluralism as well, if and when they gain enough power to ban competing candidates or parties. This is no coincidence: as Müller argues, it is written into the "inner logic" of anti-pluralist forms of populism $(2016,10-11)$. Although we cannot predict the outcome with certainty, it seems reasonable to suppose that candidates who continually demonize a particular religious or ethnic group as enemies would curb its formal political power if they could. ${ }^{24}$

\section{Three Advantages of a Pluralist Approach}

This preliminary sketch of a pluralistic approach to campaign ethics is only suggestive, of course, but we now have a clear enough picture to appreciate its key advantages over alternatives

\footnotetext{
${ }^{22}$ We thank an anonymous reviewer for raising this point.

${ }^{23}$ Famously, this is a key flaw with Schumpeter's account of democracy, and it is one reason we are not Schumpeterians in any strong sense.

${ }^{24}$ In theory, one could embrace fallibilism at the level of political institutions but not in social matters. Yet given the threat posed by political anti-pluralism to open democratic competition, and the close historical relationship between social and political anti-pluralism, we believe that at least some forms of social anti-pluralism must be definitively off-limits - even from within the limited perspective of campaign ethics.
} 
focused on honesty. First, pluralist norms are easier to enforce through decentralized sanctions. Second, even if these sanctions fail, candidates who follow pluralist norms are still less likely to seriously harm their electoral chances, and for both of these reasons, following them will less often generate perverse results. Third and finally, upholding pluralist norms is far more important for democratic politics. Thus, even if candidates lose votes by refusing to engage in anti-pluralist tactics, their sacrifice serves a worthy cause, and not an ideal that was hopeless to begin with.

Let us begin with the question of perverse results. As we have seen, existing approaches to campaign ethics seek to prohibit a wide range of deceptive practices, yet only the most unambiguous violations-blatant lies and perhaps the most egregious forms of pandering —are effectively preventable through cross-partisan sanctions. Given the very significant advantages to be gained through subtler forms of dishonesty and ambiguity, we have argued that refraining from such behaviors in the absence of broader enforcement mechanisms will often do serious damage to the electoral chances of ethical candidates.

The norms of pluralism we propose do not have the same effect. On the one hand, our account licenses certain forms of dishonesty, which gives ethical candidates a fighting chance in even the must cutthroat campaigns. On the other hand, upholding pluralism is not always or necessarily costly in the first place. Whereas ambiguity has almost no strategic downsides, anti-pluralist tactics can carry their own risks. We do not deny that those tactics are sometimes effective, even for candidates with valuable substantive goals; otherwise, there would be no genuine dilemma. However, their efficacy is far from guaranteed, and especially in the face of an anti-pluralist opponent, affirming pluralist values is not an obviously inferior response. (Compare this to the hapless candidate discussed earlier, who frets openly about the trade-offs between tax cuts and service provision while her carefree opponent promises the world). Addressing one's arguments 
to the entire political community rather than firing up one's base by demonizing the enemy may come with costs, but it may also have benefits, and in the face of this strategic uncertainty, it is ethically responsible to err on the side of pluralism.

In addition, of course, many pluralist norms are more amenable to cross-partisan sanctions than norms of honesty. Consider, for instance, that during the 2012 US presidential race, Republican nominee Mitt Romney was criticized widely, even within his own party, for calling $47 \%$ of American citizens "takers." The same thing happened four years later on the Democratic side, when Hillary Clinton sustained broad criticism—again, crucially, from many within her own party - after labeling many of her opponent's supporters a "basket of deplorables." Both Romney and Clinton backed away from their comments and did not make similar statements in the remainder of their campaigns. At least in these cases, decentralized, cross-partisan enforcement of pluralist norms seems to have worked—just as coalitions reliably mobilize within functioning democracies to marginalize actors who incite political violence.

To be sure, pluralist norms are hardly uncontestable — and as such, they will not always be enforceable by decentralized means. Indeed, many observers believe that we have recently witnessed a widespread breakdown of these norms in a number of countries around the world. Yet the very thesis of breakdown implies a prior state in which the norms were more reliably enforced. A lapse in enforcement is not evidence of structural unenforceability, but of a need to revive the conditions supporting more reliable enforcement—and that is precisely what our guidelines recommend. When sanctions fail-as they often do-this is not because enforcement is impossible, as is the case for mild forms of deception. Even in the name of valuable substantive goals, therefore, ethical candidates should not simply abandon these norms at the first sign of erosion. Given the threat that anti-pluralist tactics pose to democracy —and thus to a future in 
which substantively valuable goals may be safely pursued — candidates and their supporters must work to defend pluralist norms by abandoning any candidates who are responsible for that erosion, regardless of their substantive priorities. As demonstrated by the earlier examples, this can be an effective response in its own right. Even when such sanctions appear to be ineffective, however, this forbearance will not represent a meaningless sacrifice on the road to an inevitable arms race. Because the norms in question are at least potentially enforceable, an arms race is preventableat least in the long run — and attempting to reinstate the norms is essential to its prevention. ${ }^{25}$

Even if there is deep and seemingly unending contestation about the meaning and scope of pluralism, this is not necessarily a fatal blow to our account. After all, it was motivated in the first instance by a desire to address a set of concerns that were more significant for the health of democracy, and in that context, continuing contestation can be a feature, not a bug. Put otherwise, our account directs attention to curbing the behaviors that are most harmful to democratic forms of government, and if what results from this increased attention is increased discussion and disagreement about what those behaviors are, then our goal will have been partially accomplished.

Of the various advantages we have claimed for a pluralist theory, after all, this one is ultimately the most significant: it aims to preserve the real values of democracy.

\section{Conclusion}

In October 2018, while campaigning for Democrats in Georgia, former US attorney general Eric Holder offered a rebuttal to Michelle Obama's soaring rhetoric from the 2016 Democratic Convention. "Michelle always says 'When they go low, we go high,"' he said, before countering: "No. When they go low, we kick them"-quickly explaining that he did not mean anything

\footnotetext{
${ }^{25}$ We emphasize again that we are not opposed to norm erosion as such. As Corey Robin (2018) writes, "Some norm erosion undermines democracy, some enhances it." We believe that the norms of pluralism we have discussed, however, are fundamental to democracy.
} 
"inappropriate" or "illegal," but simply that "we have to be tough and we have to fight" (Hayes 2018). In Holder's view, in other words, "going high" is not always the right thing to do: in moral terms, the pursuit of substantive ends sometimes demands that candidates get their hands dirty. Doing so is not only excusable; it may also be the ethical candidate's responsibility.

In this article, we have offered some support for this view, and we have also articulated what it means for an ethical candidate to fight. Unlike previous theorists of campaign ethics, we maintain that "going high" is not always the right response for ethical candidates. In other adversarial circumstances, we often license behaviors that would normally be considered unethical, and this should apply to elections as well. When elections have important normative consequences, we should not ask ethical candidates to fight unscrupulous opponents with one hand tied behind their backs. At the same time, we agree with prior accounts that campaigns cannot simply be treated as an ethics-free zone. When ethical candidates contemplate using "dirty tactics" to help them achieve valuable substantive goals, they must consider the detrimental effects of those tactics on democratic norms and institutions - and some tactics must be considered beyond the pale altogether. (If Holder were calling for Democrats to adopt a win-at-any-cost approach, we would disagree with his exhortation). But our ethical calculations should be guided by a realistic conception of democracy's value, and they should not doom ethical candidates to defeat. In response, we suggested an approach to campaign ethics that emphasizes social and political pluralism, allowing candidates to fight to win while nonetheless curbing the most destructive tendencies of competitive campaigns. 


\section{References}

Achen, Christopher H., and Larry M. Bartels. 2016. Democracy for Realists: Why Elections Do Not Produce Responsive Government. Princeton: Princeton University Press.

Ahlquist, John S., Nahomi Ichino, Jason Wittenberg, and Daniel Ziblatt. 2018. "How Do Voters Perceive Changes to the Rules of the Game? Evidence from the 2014 Hungarian Elections." Journal of Comparative Economics 46 (4): 906-19.

Applbaum, Arthur Isak. 2000. Ethics for Adversaries: The Morality of Roles in Public and Professional Life. Princeton: Princeton University Press.

Arrow, Kenneth. 1951. Social Choice and Individual Values. New York: John Wiley \& Sons.

Baderin, Alice. 2014. “Two Forms of Realism in Political Theory." European Journal of Political Theory 13 (2): 132-53.

Bagg, Samuel. 2016. "Between Critical and Normative Theory: Predictive Political Theory as a Deweyan Realism." Political Research Quarterly 69 (2): 233-44.

Bagg, Samuel. 2017. "When Will a Darwinian Approach Be Useful for the Study of Society?" Politics, Philosophy \& Economics 16 (3): 259-81.

Bagg, Samuel. 2018a. “Can Deliberation Neutralise Power?” European Journal of Political Theory 17 (3): 257-79.

Bagg, Samuel. 2018b. "The Power of the Multitude: Answering Epistemic Challenges to Democracy." American Political Science Review 112 (4): 891-904.

Bagg, Samuel. 2018c. "What Makes a Political Theory Political? A Comment on Waldron." Political Studies Review 16 (3): 184-91.

Bartels, Larry M. 2002. "Beyond the Running Tally: Partisan Bias in Political Perceptions." Political Behavior 24 (2): 117-150.

Beerbohm, Eric. 2012. In Our Name: The Ethics of Democracy. Princeton: Princeton University Press.

Beerbohm, Eric. 2016. "The Ethics of Electioneering." Journal of Political Philosophy 24 (4): $381-405$.

Boyte, Harry C. 2010. Everyday Politics: Reconnecting Citizens and Public Life. Philadelphia: University of Pennsylvania Press.

Bretherton, Luke. 2014. Resurrecting Democracy: Faith, Citizenship, and the Politics of a Common Life. New York: Cambridge University Press. 
Connolly, William E. 1991. Identity, Difference: Democratic Negotiations of Political Paradox. Minneapolis: University of Minnesota Press.

Disch, Lisa. 2011. "Toward a Mobilization Conception of Democratic Representation." American Political Science Review 105 (1): 100-114.

Dresden, Jennifer Raymond, and Marc Morjé Howard. 2016. "Authoritarian Backsliding and the Concentration of Political Power." Democratization 23 (7): 1122-43.

Galston, William. 1991. “Toughness as a Political Virtue.” Social Theory and Practice 17(2): 17597.

Galston, William. 2010. "Realism in Political Theory." European Journal of Political Theory 9 (4): 385-411.

Galston, William. 2018. Anti-Pluralism: The Populist Threat to Liberal Democracy. New Haven: Yale University Press.

Grattan, Laura. 2016. Populism's Power: Radical Grassroots Democracy in America. New York: Oxford University Press.

Green, Jeffrey Edward. 2009. The Eyes of the People: Democracy in an Age of Spectatorship. Oxford: Oxford University Press.

Hayes, Chrystal. 2018. "Eric Holder Says Michelle Obama Was Wrong: 'When They Go Low, We Kick Them." USA Today.

Heath, Joseph. 2006. "An Adversarial Ethic for Business: Or When Sun-Tzu Met the Stakeholder." Journal of Business Ethics 72 (4): 359-74.

Hellmann, Jessie. 2016. "Clinton: 'Ugliness,' and 'Bigotry' the Best Trump Can Do.” The Hill, http:/thehill.com/blogs/ballot-box/presidential-races/296252-clinton-calls-trumpsbirther-comments-as-ugly-and-bigoted.

Ingham, Sean. 2018. "Why Arrow's Theorem Matters for Political Theory Even if Preference Cycles Never Occur." Public Choice 1-15.

Kahan, Dan M., Donald Braman, John Gastil, Paul Slovic, and C. K. Mertz. 2007. "Culture and Identity-Protective Cognition: Explaining the White-Male Effect in Risk Perception." Journal of Empirical Legal Studies 4 (3): 465-505.

Kirshner, Alexander S. 2014. A Theory of Militant Democracy: The Ethics of Combating Political Extremism. New Haven: Yale University Press.

Kirshner, Alexander S. 2016. "Legitimate Opposition, Ostracism, and the Law of Democracy in Ancient Athens." Journal of Politics 78 (4): 1094-1106. 
Kunda, Ziva. 1990. "The Case for Motivated Reasoning." Psychological Bulletin 108 (3): 480498.

Lakoff, George. 2004. Don't Think of an Elephant! Know Your Values and Frame the DebateThe Essential Guide for Progressives. White River Junction, VT: Chelsea Green.

Lau, Richard R., Lee Sigelman, and Ivy Brown Rovner. 2007. "The Effects of Negative Political Campaigns: A Meta-Analytic Reassessment.” Journal of Politics 69 (4): 1176-1209.

Levitsky, Steven, and Daniel Ziblatt. 2018. How Democracies Die. New York: Crown.

Lipsitz, Keena. 2004. "Democratic Theory and Political Campaigns." Journal of Political Philosophy 12 (2): 163-189.

Lodge, Milton, and Charles S. Taber. 2013. The Rationalizing Voter. Cambridge: Cambridge University Press.

Maisel, L. Sandy. 2002. "Promises and Persuasion." In Shades of Gray: Perspectives on Campaign Ethics, eds. Candice J. Nelson, David A. Dulio, and Stephen K. Medvic, 39-60. Washington, DC: Brookings Institution Press.

Maloy, Jason Stuart. 2013. Democratic Statecraft: Political Realism and Popular Power. Cambridge: Cambridge University Press.

Mansbridge, Jane. 2003. "Rethinking Representation.” American Political Science Review 97 (4): $515-528$.

McGraw, Kathleen M., Milton Lodge, and Jeffrey M. Jones. 2002. "The Pandering Politicians of Suspicious Minds." Journal of Politics 64 (2): 362-83.

McKean, Benjamin L. 2016. "Toward an Inclusive Populism? On the Role of Race and Difference in Laclau's Politics." Political Theory 44 (6): 797-820.

Medearis, John. 2015. Why Democracy Is Oppositional. Cambridge, MA: Harvard University Press.

Medvic, Stephen K., and Dale E. Miller. 2002. “Civic Responsibility or Self-Interest?” In Shades of Gray: Perspectives on Campaign Ethics, eds. Candice J. Nelson, David A. Dulio, and Stephen K. Medvic, 18-38. Washington, DC: Brookings Institution Press.

Mickey, Robert, Steven Levitsky, and Lucan Ahmad Way. 2017. "Is America Still Safe for Democracy?" Foreign Affairs (May/June).

Mouffe, Chantal. 2005. The Return of the Political. London: Verso.

Mouffe, Chantal. 2018. For a Left Populism. London: Verso.

Müller, Jan-Werner. 2016. What Is Populism? Philadelphia: University of Pennsylvania Press. 
Norman, Wayne. 2011. "Business Ethics as Self-Regulation: Why Principles that Ground Regulations Should Be Used to Ground Beyond-Compliance Norms as Well.” Journal of Business Ethics 102 (1): 43-57.

Przeworski, Adam. 1999. “Minimalist Conception of Democracy: A Defense.” In Democracy's Value, eds. Ian Shapiro and Casiano Hacker-Cordon, p. 23-55. Cambridge: Cambridge University Press.

Przeworski, Adam. 2010. Democracy and the Limits of Self-Government. Cambridge: Cambridge University Press.

Przeworski, Adam. 2018. Why Bother With Elections? Cambridge: Polity.

Riker, William H. 1982. Liberalism against Populism: A Confrontation between the Theory of Democracy and the Theory of Social Science. San Francisco: Freeman Press.

Robin, Corey. 2018. "Democracy Is Norm Erosion." Jacobin, December 20, http://jacobinmag.com/2018/01/democracy-trump-authoritarianism-levitsky-zillblattnorms.

Rosenblum, Nancy L. 2010. On the Side of the Angels: An Appreciation of Parties and Partisanship. Princeton: Princeton University Press.

Schumpeter, Joseph. 1942. Capitalism, Socialism, and Democracy. New York: Harper.

Shapiro, Ian. 1999. "Enough of Deliberation: Politics Is about Interests and Power." In Deliberative Politics: Essays on Democracy and Disagreement, ed. Stephen Macedo, p. 28-38. New York: Oxford University Press.

Shapiro, Ian. 2016. Politics against Domination. Cambridge, MA: Belknap Press.

Singer, Abraham. 2018. The Form of the Firm: A Normative Political Theory of the Corporation. New York: Oxford University Press.

Sleat, Matt. 2016. "Realism, Liberalism and Non-Ideal Theory: Or, Are There Two Ways to Do Realistic Political Theory?” Political Studies 64 (1): 27-41.

Somin, Ilya. 2013. Democracy and Political Ignorance: Why Smaller Government Is Smarter. Stanford, CA: Stanford University Press.

Stout, Jeffrey. 2012. Blessed Are the Organized: Grassroots Democracy in America. Princeton: Princeton University Press.

Svolik, Milan. 2018 "When Polarization Trumps Civic Virtue: Partisan Conflict and the Subversion of Democracy by Incumbents." SSRN: DOI: 10.2139/ssrn.3243470

Weale, Albert. 2018. The Will of the People: A Modern Myth. Cambridge: Polity. 